\title{
Transatlantica
}

Revue d'études américaines. American Studies Journal

$1 \mid 2012$

Le roman policier, littérature transatlantique / Maisons

Hantées

\section{The Mechanics of Fear: Organic Haunted Houses in American Cinema}

Anne-Marie Paquet-Deyris

\section{(2) OpenEdition \\ Journals}

Electronic version

URL: https://journals.openedition.org/transatlantica/5988

DOI: 10.4000/transatlantica.5988

ISSN: 1765-2766

\section{Publisher}

Association française d'Etudes Américaines (AFEA)

Electronic reference

Anne-Marie Paquet-Deyris, "The Mechanics of Fear: Organic Haunted Houses in American Cinema", Transatlantica [Online], 1 | 2012, Online since 23 April 2013, connection on 01 February 2023. URL:

http://journals.openedition.org/transatlantica/5988 ; DOI: https://doi.org/10.4000/transatlantica.5988

This text was automatically generated on 1 February 2023.

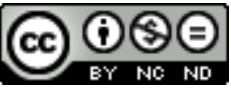

Creative Commons - Attribution-NonCommercial-NoDerivatives 4.0 International - CC BY-NC-ND 4.0

https://creativecommons.org/licenses/by-nc-nd/4.0/ 


\title{
The Mechanics of Fear: Organic Haunted Houses in American Cinema
}

\author{
Anne-Marie Paquet-Deyris
}

1 Most haunted house narratives, whether literary or filmic, are based on the same basic principle of intrusion of some outside, usually unidentified force which sows the seeds of chaos and destruction within the boundaries of a home. What is particularly fascinating is precisely the way in which the group, and most often the family, reacts to this external force. But the whole point is also to determine the exact nature of the threat and to assess who-or what-the intruder is, so as to circumscribe "it" and return the community to some form of normality. In this respect, even though a direct descendant of a more conventional haunted house film genre, the 1980s family horror imposes a reversal of viewpoints. It actually seems to be reverting to some more classical Hollywood narrative structures after the bloodbaths of the previous decade in horror feasts, such as The Hills Have Eyes (1977) or Dawn of the Dead (1978), which argued then for a new form of society. It also demonstrates how the outside-the-norm entity is finally not considered exogenous any more but rather endogenous and how it appropriates and somehow tries to incorporate some, if not all, members of the household.

2 Playing diversely on the Greek etymology of the term phenomenon (phainestai/to appear), writers and directors alike focus on the apparitional modes of the various manifestations emanating from the haunted houses. The trajectory from inner consciousness to some exteriorized and communal form of perception somehow redoubles the literally extra-ordinary emergence of supernatural forces. So that in the course of events, Todorov's assertion that fantasy is grounded in a rational being's hesitation as to the nature of some apparently supernatural phenomenon is no longer valid, since natural laws no longer apply.

3 Most movie-makers, working within some well-established conventions, toy with the memory of the genre. Rearranging the old topos of the haunted house dating back to 
masterpieces such as Paul Leni's 1927 The Cat and the Canary or Robert Wise's 1963 The Haunting adapted from Shirley Jackson's novel The Haunting of Hill House (1953), they consistently stage the Gothic house as rooted in a specific type of history. But in the 1980 s, to this privileged anthropomorphic territory was often added a new, actualized dimension having little to do with the core of America's historical consciousness. A different kind of house, no longer darkened and isolated in some desolate part of the American East Coast takes center stage. Two of the most intriguing haunted house films of the decade feature a nondescript city house characteristic of the West Coast urban sprawl. Not unlike the next one on the block, or even belonging to the same housing development, it nevertheless comes alive through the impetus given by some obscure catalizer. And the same question reemerges: what's the true nature of the haunting? The cryptic, cumulative trajectory of fear still informs the filmic narrative. The basic tenets of the haunted house tale are nevertheless reactualized, as the protagonists are no longer isolated, as in The Shining (Kubrick, 1980), The Innocents (Clayton, 1961) or The Others (Amenabar, 2001). They constantly live and interact with others, filling in the surrounding space and screen. And this is somehow matched by the full use of special effects, powerfully materializing the psychic and disturbingly organic phenomena occurring within the frame. Effects call for affects here, greatly contributing to a new construction of the fear factor.

\section{Engineering fear}

4 In his 1981 film The Entity, Sidney Furie stages Barbara Hershey's body (Carla Moran) as a vehicle for the revelation process and in their 1982 Poltergeist, Tobe Hooper and Steven Spielberg who actually did much more than just produce the film, also use young Heather O'Rourke (Carol Anne Freeling) as a medium. Most of what these two protagonists convey is precisely at the heart of the design of fear. As film scholar Cosimo Urbano underlines:

what is essential to the modern horror film is not the mere presence of a monster but a set of peculiar and specific feelings that the films elicit in their viewers. [...] modern cinematic horror deploys four basic formal strategies (the representation of the monster being, incidentally, one of them) to elicit them. At the core of my argument, therefore, lies the idea that what is characteristic of, and necessary to, the modern horror film is neither its monsters nor its typical narrative pattern, but rather a specific spectatorial affect, namely anxiety. [A]ll of these viewers will share, or so I argue, the expectation that (at least non-parodic) horror films will try to make them anxious. ${ }^{1}$

Of course, anxiety is not fear, but it seems somehow to predate it and even eventually generate it, at times in the most banal of locations. During the Reagan years (1981-1989), and in the next decade as well, California becomes a stereotypical American place hit hard by what Christopher Sharrett calls "the rollback in social/ economic justice and racial tolerance of the Reagan/Bush/Clinton epoch" (Sharrett, 1999, 11). It experienced an unprecedented increase in new residents and became a prime destination for undocumented immigrants (about one quarter of the newcomers) generating intense public debates and anxieties over job opportunities for natives. The sense of threat to some "native norm" and way of life starts registering on screen in a variety of ways. 
6 Each house in The Entity and Poltergeist is set in California in common surroundings, Los Angeles in Furie's movie and the suburbs of Santa Barbara in Hooper's. In the two films' opening sequences, what lies behind the house's commonplace facade quickly becomes the center of the spectator's gaze. It operates somehow as visual bait, forcing the spectator to question its very function: what does it have to hide and to what extent can it gradually become a demonic structure trapping its inhabitants inside?

7 In The Entity's long opening sequence, the first establishing shot is a night shot capturing the house frontally, as if for sale on some real estate catalogue. As if to prove Richard Maltby's assertion that the horror film is an "additional category" (Maltby, 1995), such an inscription on screen already discloses an element of the bizarre which will soon connote the emergence of the horrific mode. The play on light and darkness and the dancing shadows of leaves on the facade already signal the potential eruption of some alien dimension. It seems to be shining of its own accord, even after Carla's headlight shot in close-up has been turned out. But the spectator's discomfort has not fully arisen yet and the main protagonist's unsuspecting view of the house is still predominant. This alternation between two categories of gaze, the culturally suspicious gaze of the viewer and the ordinary trusting one of the main character, reflects the fluctuating boundaries of the horror genre. Engineering such an interpretative gap until the protagonist can feel as well the house's powerful sway over her/him seems to be the director's primary goal.

8 In Poltergeist, the opening overviews of the city of Cuesta Verde also play on this discrepancy between a realistic approach and some still muffled expression of difference. The high-angle distance shots of the entire city nestling in the California foothills are replaced with closer shots of the streets, neighbourhood, and people, until the camera can eventually focus on the members of the Freeling family at home. It also briefly frames the "Cuesta Verde Sales Information \& Model Homes" advertizing sign insisting on the identical houses and manicured streets, and constructs an ironically idealized all-American, suburban environment. Token images of the American Dream also register on screen as the camera shows Steve Freeling (Craig T. Nelson) and his friends gathered together in the living room watching a football match on television. The banal dimension of these male social rituals further emphasizes the normality of the whole scene, preparing us somehow for a rather violent outburst of abnormal events. Hence the approach to the phenomenon of fear differing radically from the disquietening presentation of the house by Robert Wise in The Haunting (1963) for instance, or Stuart Rosenberg in Amityville (1979). In Wise's classic, Hill House is framed from the start in a slightly oblique angle as a dark animalistic form seemingly endowed with a will of its own. The crooked mansion's outline standing out against a sky in chiaroscuro and the chilling voiceover which starts telling its evil story already give the surreal a palpable shape and sound. Rosenberg's introductory sequence is even more terrifying as the somber massive shape of the Long Island house is set against a blood-red backdrop reflected in the two eye-shaped windows of the upper storeys. The horror film's generic chromatic palette is already encoded in the first master shot. Even before the arrival of the Lutz family, surreality shines through the facade of middleclass normality and naturalism. These two opening sequences are obviously "generically modelled," as film theoretician Steve Neale asserts in Genre and Hollywood. Horror conventions condition both production and reception and thus instantly propell the spectator into a-by then-carefully formatted atmosphere. 
With Furie and Hooper, these prerequisites are not immediately inscribed on screen. At the beginning of the 1980s, the setting is no longer the East but the West Coast. The latter is traditionally represented as being somewhat freer than the East of some stifling historical dimension, and often synonymous with a new form of settlement, the uniform housing developments mostly suggesting serial production, almost like Le Corbusier's serial house. Curiously enough, uniformity seems to have then become the heart of another coherent syntax. The very stability of this syntax appears to have thus guaranteed the durability of this new type of haunted house film subgenre. In turn, the spectator of the 1980s has become quickly conditioned by a new semantics and recurring syntax somehow matching and bringing forth slightly different syntactic strategies, once again "subjecting well-known semantic units to a syntactic redetermination" (Altman, 225).

In such texts as Mary Shelley's Frankenstein, Balzac's La Recherche de l'absolu, or Stevenson's Dr. Jekyll and Mr. Hyde, a studied syntax equates man and monster, attributing to both the monstrosity of being outside nature as defined by religion and science. With the horror film, a different syntax rapidly equates monstrosity not with the overactive nineteenth-century mind, but with an equally overactive twentieth-century body. Again and again, the monster is identified with his human counterpart's unsatisfied sexual appetite, thus establishing with the same primary 'linguistic' materials (the monster, fear, the chase, death) entirely new textual meanings, phallic rather than scientific in nature. [...]

Spectator response, I believe, is heavily conditioned by the choice of semantic elements and atmosphere, because a given semantics used in a specific cultural situation will recall to an actual interpretive community the particular syntax with which that semantics has traditionally been associated in other texts. This syntactic expectation, set up by a semantic signal, is matched by a parallel tendency to expect specific syntactic signals to lead to predetermined semantic fields [...]. (Altman, 224-25)

10 In the movies' opening sequences, two ordinary families attend to everyday business and the spectator automatically becomes somewhat of a voyeur when the camera takes him inside. This initial spectatorial intrusion foreshadows the monstrous one to come as some alien element rising from the inside starts wreaking havoc in a formerly orderly private space. But much like the house inhabitants, as he steps in, the spectator still retains some ambivalent position in between the public and the private spheres. And the interaction of the two dimensions may be the major distinction with more "classically" modelled haunted house films.

11 In Furie and Hooper's works, the stories of the Moran and the Freeling families undergo radical changes in the course of the filmic narratives and by no means reflect their former lifestyles. The inscription of violent events can take center stage precisely because there has been no prior emergence of the supernatural. Making a breach in the appalling normality of suburbia is what the directors seem to be primarily interested in. The process of possession is first materialized on screen by the violation of the mother's body in The Entity and the literal absorption of the little girl's in Poltergeist. In the latter movie, one of the most disturbing scenes simply shows Carol Anne talking to the empty white screen of the television set by night. She already seems to be poised on the edge of doom and irretrievably attracted to The Other Side, which actually became the subtitle of Poltergeist II (Brian Gibson, 1986). And the inherent ambiguity of the horror film is already framed in the strange pseudo-dialogue between the child and the "TV people." In an eerie doubling effect, the TV frame within the larger frame of the screen magnifies the potent fascination effect of both the character and the spectator. 
Carol Anne answers the inaudible questions of some unseen and unnamed entity across this symbolic sill. As she gazes at this off-screen space, what French film critic Marc Vernet calls the "en-deça" $(1988,57)$-what lies on this side but cannot be seen, the ghostly persistence of some invisible supernatural presence-resurfaces. At this stage in the filmic narrative, this in-between space figures more a point of expression than a fully-constituted point of view. Ironically, this invisible channel also functions as a point of intersection between the public and private spheres. The intrusion of mass media materialized by the proliferation of TV sets in the house may well materialize the brutal dilation of the public sphere into the private one, but Carol Anne's answers to the disembodied entity remain simple, effective, "[I'm f]ive;" "Yes," "I don't know," before she presses her hands onto the screen in an inviting gesture. The contrast between the previous series of pixellized images staging key moments in the history of the United States (the national anthem or the flag at Iwo Jima for instance) and this moment of intimacy highlights however the vulnerability of the child's exposed body. The TV screen reflects the same discreet sense of threat as the front of the house in the first shots. It becomes a second facade about to let through some uncontrollable forces. Yet another standardization device like the serial house, it is also about to turn into an instrument of distortion and fundamental ambivalence. In a twofold movement, it will conjointly hide the presence of the spirits trapped in the house as their bodies were displaced to make room for the new estate, and disclose their elusive presence.

The materialization and dematerialization of the body take center stage in the battle between evil forces and family members as the image box, much like the toy closet in Carol Anne's bedroom, stops being the core of family life to become the regulator of a whole system of appearances of ghosts and monsters. Turning into an abnormal stage, it lets forces from beyond filter through the crack the child created between two parallel universes with their own laws of physics. The remaining part of the filmic narrative then revolves around devising strategies to counteract the endless flux of invaders pouring into the house and to bring the child back from this dark other side.

\section{Locus horribilis}

13 Images of the body under the sway of some evil forces seem to elicit the most effective -and affective-responses of fright or fear. The central motif of the body about to disintegrate and disappear is explored in a different but potent manner in Furie's The Entity. In his 1978 source novel, Frank De Felitta describes the first attack on Carlotta (Carla in the film) as a violent displacement of, and intrusion into, her body by some invisible emanation from an expecting house "holding darkness within," just like Hill House in Shirley Jackson's novel $(2006,1 ; 182)$ :

The house was deathly quiet. It seemed to her the whole world was asleep. This was what she remembered thinking-before it happened. One moment Carlotta was brushing her hair. The next she was on the bed, seeing stars. Some knock, like being hit by a charging fullback, plummeted her across the room and onto the bed. In a blank mind, she realized that the pillows were suddenly around her head. Then they were smashed down over her face. [...]

Her body must have been thrashing without her knowing it, because now it was grabbed and grabbed hard. (De Felitta, 1978, 20)

In the adaptation, after the long opening sequence of The Entity, Carla is getting ready for the night, partly reflected in her dressing table mirror. The dissociation effect 
between her body and its reflection is accentuated by the voyeuristic eye of the camera. It closely frames the young woman in a series of visual caresses as she applies body cream before capturing her being violently assaulted in some "kinesics of suffering," to borrow from Adrienne McLean's article title, "Feeling and the Filmed Body: Judy Garland and the Kinesics of Suffering" (Film Quarterly, vol. 55, n 3, Spring 2002). In this brutal body semantics, the character's suffering and utter surprise at the savage experience are fully exposed, foregrounding the unexplainable dimension of the phenomenon. Somehow, as Laura Mulvey was already underlining over thirty years ago in her ground-breaking essay "Visual Pleasure and Narrative Cinema," the spectacle first reproduces the illusion of voyeuristic separation most films toy with.

But the mass of mainstream film, and the conventions within which it has consciously evolved, portray a hermetically sealed world which unwinds magically, indifferent to the presence of the audience, producing for them a sense of separation and playing on their voyeuristic phantasy. (In Merck, 1999, 24)

The main point here seems also to be that the "illusion of looking in on a private world" (ibid.) does not construct a traditionally erotic object for the spectator but rather one for the exclusive benefit of the unseen force objectifying Carla, even if the movie was rated " $R 18$ " when it was released. At the core of the film's representational strategy, this visual portrayal of physical violence is somehow in keeping with what Frank Tomasulo calls a form of Reagan-era "[p]ervasive violence [that] has become endemic to the American mythos, almost to the point of being an accepted part of our national character or 'genetic' makeup often with no obvious social, historical, or psychological causation" ("Raging Bully: Postmodern Violence and Masculinity in Raging Bull," in Sharrett and Grant, 1999, 176). But as the heroine fights back, she rejects in a very masculine way the burden of sexual objectification, desperately trying to preserve her integrity and, literally as well as figuratively, the limits of her own body. As film theoretician Shohini Chaudhuri underlines while exploring Barbara Creed's theories,

In The Monstrous-Feminine, Creed extends to the horror film the structures of abjection that Kristeva, in her book Powers of Horror (first published in 1980), discusses in relation to literature. Although the abject is, ultimately, part of ourselves, we reject it, expelling it and locating it outside the self, designating it as "not-me," in order to protect ourselves. [...]

The second aspect of abjection in the horror film lies in the collapsing of boundaries or boundary ambiguities. The monster is what "crosses or threatens to cross the 'border'," for example the border between human and non-human; natural and supernatural; normal and abnormal gender behaviour and sexual desire [...]. (In Chaudhuri, 2006, 93)

As early as the movie's second sequence, the monster is constructed as an invisible "body snatcher," unexpectedly eradicating the limit between natural and supernatural. Norms are suddenly invalidated, as Carla Moran doesn't seem to be living in the house any more but is rather possessed by it, "lived in" by a demonic entity tampering with the entire space-time system of the household. The spectator's stunned reaction replicates the character's own efforts at gaining mastery over fright. The visual effects of misframing and oblique angles, objects and fragments of body framed in high- and low-angle shots and extreme close-ups all materialize on screen the process of the house taking possession. Danger comes from within, and the house turns into a trap operated by some ungraspable agent. As in Wise's classic, The Haunting, supernatural occurrences are always preceded by iconoclastic angle shots, upsetting our rational 
perception of space and, consequently, of time as well since the phenomenon seems to have travelled through the ages to strike again in the contemporary era.

Staging the house as a psychic space is one of the sources of fascination in Furie's adaptation of De Felitta's novel. At first, all the characters Carla talks to about her monstrous attacks question the validity of her story as in the slightly low-angle, chiaroscuro shot of her son Billy staring open-mouthed at her. So does Phil Sneiderman (Ron Silver), the psychiatrist she eventually sees and who diagnoses the attacks as a projection of what she fears about herself, thus in turn reinforcing the analogy between the house and the psyche. Such an equation between the two loci is consistently sustained throughout the film as Carla is shown being assaulted even outside the house, as if her body itself had become a haunted space, a locus horribilis, as well as a mere helpless receptacle. Sneiderman officially exposes his theory as he visits Carla's house and explains the mechanism of childhood traumas inducing mental disorders. Framed in a two-shot as she looks up at the lit-up house front by night, the heroine quietly maintains: "There is really something there." In the movie, the haunted house topos is partly reinvented thanks to the expansion of the arena of the haunting. Just as the body limits are being tampered with, so is the notion of "safe" space surrounding it. Contrary to classic horror tales, the haunting is no longer restricted to the house which, in turn, is not insulated from the outside world. Far from functioning merely in autarky, it is animated by all kinds of at times antagonistic fluxes registered on screen by smoke traces or even light rays, as in Poltergeist. The house's tendency to close up on itself and its preys is still represented however by foregrounding non-observance of the rule of perspective, thus creating a loss of reference marks and causing the character and spectator's terror alike. Because the house remains nevertheless open onto the exterior, counter-forces such as teams of parapsychologists in both films, or Carla's friend Cindy in The Entity, can interact, fight the house's hegemonic views and eventually expose the haunting phenomenon. As it needs to be authenticated by outsiders in order to be mastered, both Furie and Hooper focus on photographic proof. Some of the films' most spectacular shots are actually photos in extreme close-up like the one of the supernatural rapist's form highlighted by flashes of lightning appearing under an eye-shaped lens in The Entity. In Poltergeist, multiple illuminated human forms are also being recorded on film as scientific proof, constituting thus a brilliant display of-at the time-spectacular and horrifying special effects.

This obsession with turning phenomena into facts seems to be a characteristic trait of films of the 1980s, including Stuart Rosenberg's 1979 The Amityville Horror. It somehow reinforces the idea that the house is structured like a live organism where parallel systems operate without necessarily cooperating. This new locus horribilis is by no means structured exclusively along a vertical axis modelled on Paul Leni's The Cat and the Canary, from the mansion's upper stories to the cellar. And if some inhabitants seem to become increasingly dependent on it and are eventually absorbed by it, they mostly keep coming in and out of this troubled space revealing its peculiar topography.

In these movies, the television screen and the mirror both act as gateways between two planes of existence, the horizontal, terrestrial and human plane and the vertical, supernatural one through which occult forces invade the familial space. When Carol Anne crosses over into the occult plane in Hooper's film, she herself turns into a light beam, a bright "life force" as psychic Tangina Barrons (Zelda Rubinstein) explains, and eventually becomes the medium through which the house's lost souls will escape Hell's 
limbo. Beyond this rather hackneyed screenplay, the notion of fusing with a specific place and being diffused, almost diffracted, through space is what allowed Spielberg and Hooper to break away from the stereotypical scenes of the haunted house subgenre. The humorous notes, critical distance with the characters and situations and the dazzling special effects of floating objects or humanoid drapes of light often bend generic conventions of horror such as playing with off-screen events, the unspoken or mere suggestion. But such breaks also underscore the more canonical dimension of some of the film's sequences, as when the mother, Diane Freeling, is attacked in her bathtub by evil forces, or later on in the filmic narrative, when she has to go down a nightmarishly elongated corridor in order to save her children.

In this film, deliberately hesitating between a more "conventional" Fantastic genre (with its violated burial places, abandoned dead bodies or rising skeletons) and a more "technological" one (with its computer-generated monsters), the focal point nevetheless remains the idea that the average American family can break free of the vampiric sway of the house and overcome it-to a certain extent. The last scenes in Poltergeist inscribe on screen the brutal eradication of the vertical axis emblematic of what Stephen King calls "the archetype of the Bad Place" $(1983,266)$ in Danse Macabre.

\section{Fleeing the inside}

To various degrees, however, the films' concluding sequences insist on the necessity of fleeing the inside, of literally extricating oneself from a contaminated space. In this sense, the shock sequence of deliverance at the end of Hooper's movie plays on the idea that the hidden interiority of American households may also be shameful and monstrous. In a properly spectacular catharsis, Diane rescues Carol Anne and both mother and daughter emerge from the other side conspicuously covered in some gory mucus and amniotic fluid fighting their way along a rope/umbilical cord. In this somewhat confusing staging of horror combining children's psychological fears, adult frustrations, psychic dynamics and plain Gothic, Suburbia is treated by Spielberg as

a lake of contradictory wishes and impulses which can be expressed in forms either beatific or horrific [while] for Hooper, it is more simply the graveyard of American consumerism, bloated on TV, a fit target for assassination by Nature and the Past. (Auty, 1982, 206)

However philosophically and aesthetically incompatible these two styles of horror may be, this critical viewpoint on American society can only be expressed if the house reflects and projects this uniform, sterile quality of quite a few American families. In the two movies, the house comes to life, functions autonomously and takes on an organic dimension but is eventually partly defeated. Carol Anne's second birth mimicks the bloody expulsion of the child's body and its intake of breath when being washed in the bathtub. The girl is thus apparently cleansed of all demonic influences. But precisely, the ritual cleansing often remains laden with ambiguity.

In The Entity, Carla Moran is framed in a sumptuous chiaroscuro close shot trying to touch the electric outline of her supernatural rapist. Surrounded by the scared scientists and their monitoring equipment, she starts shouting exuberantly: "He's weak. I can't believe it. He can't touch us. Die you bastard, die!” These two sequences foreshadow the heroes' final and relative release as they return to their own liberated flesh. Their bodies are therefore restored to life within the norm and hence to the 
desperately standardized aspect of American lifestyle, as opposed to the classic haunted house opus where characters end up abandoning themselves to the castle's dark power like Eleanor Vance (Julie Harris) in Wise's The Haunting. Perfect fusion as if by osmosis between the heroine and the house may characterize these old East Coast mansions but by no means apply to the modern West Coast tract houses steeped, as previously seen, in some lesser historical depth. Actually in Hooper and Spielberg's movie, the Gothic disturbed-ancient-burial-grounds trail seems mostly to function as a secondary motivation for why such phenomena are happening. Hence the difficult, if not impossible, compatibility between the various horrific storylines. In the end, regeneration marks only the protagonists' bodies as opposed to the house's ominous mass and whatever "walk[s] there" (Jackson, 2006, 1).

For numerous 1980s directors then, revising the genre and literally recasting the haunted houses and their inhabitants entail a final inversion of the endless reenactment of the curse. While Eleanor gets killed and is claimed as their own by the mansion and its former owner Hugh Crain, and while the Lutz family virtually repeats the previous tragedy at the Long Island house on Ocean Avenue, the Morans and the Freelings irrevocably cut the cord with their West Coast houses. In other terms, the body is relatively safe because the house is either forever abandoned or utterly destroyed. The concluding sequences intensely focus on the brutal ritual of separation, materializing the end of the alienating relation to the house. As the disincarnated voice of the rapist welcomes Carla back in the house with a chilling "Welcome home, cunt!", the camera frames in an oblique extreme close-up her hand turning the door knob before she slowly but resolutely joins her family outside. Mastery over fear registers on screen in one single fluid movement of the hand. The caption surperimposed on the eerie high-angle vertical travelling shot over the house makes a claim for a basis in truth which is distinctive of most self-respecting horror films in the 1980s:

The film you have just seen is a fictionalized account of a true incident which took

place in Los Angeles, California, in October 1976.

It is considered by psychic researchers to be one of the most extraordinary cases in

the history of parapsychology.

The real Carla Moran is today living in Texas with her children.

The attacks, though decreased in both frequency and intensity...

Continue.

Somehow the inscription reflects the novel's preliminary statement "taped in the presence of Officer John Flynn, \# 1730522" (De Felitta, 1978, 13).

Ironically, Poltergeist's last but one scene functions in inverse proportion, as the Freeling house literally implodes like a television set in a feast of special effects expelling its members in full view onto the front lawn. The sequence is fascinating not so much because of its technicity as because for the first time, skeptical neighbors eventually witness and believe in what Jay Anson calls in his afterword to The Amityville Horror, "one of those dark mysteries that challenges our conventional accounting of what this world contains" (Anson, 315). Somehow, the haunted house cannot seem to disappear without being erased from the field of view, dissolved into nothingness without being rejected into the off-screen space. The house vanishes once its interiority has been fully exposed to the other's gaze and its inhabitants restored to the banal and horizontal dimension of simple humanity. In Hooper's movie, the distance imposed by the outsider's gaze underscores the regenerative dimension of changing habitats. In some ultimate humoristic effect, the battered Freeling family ends up in a local Holiday 
Inn room from which the father dutifully banishes the TV set. And this final shot reminds the spectator that a good deal of the story is mainly structured around the trite intrusion of spirits through the TV screen.

Somehow, both films prove to be what their predecessors were ardently wishing for: a laboratory experiment-a fixture which they also both feature. As Jay Anson was already underlining in his 1977 novel,

It would be helpful if we could duplicate, as in a controlled laboratory experiment, some of the events the Lutzes experienced. But of course we cannot. Disembodied spirits-if they exist-presumably feel no obligation to perform instant replays before the cameras and recording equipment of earnest researchers. (Anson, 2005, 314)

But it is precisely what Furie, Hooper and Spielberg did, sometimes playfully, in their filmic adaptations, at times playing with the very representation of such an experiment as when The Entity parapsychologists set up a replica of Carla's house and spray the trapped force with liquid helium to define its shape, before it can escape. The dreamlike quality of photography, with its volutes of steam and white smoke and fuzzy images retranscribed on the monitor, already provides a fascinating reformatting of conventional representations of the occult.

Circumventing the basic principle of infinite repetition, these two experiments in the mechanics of horror impose other horrific rules such as staging in a highly sexualized or bizarre way of the dispossession of the self and the absorption of one's body by some alien force. But the point is not so much to highlight the haunting process as to capture on screen the characters' terrified reaction to it. Once the haunting chain has been broken, only unsettling traces of some parallel and disturbingly violent universe resurface.

\section{BIBLIOGRAPHY}

ANSON, Jay, The Amityville Horror, New York, Pocket Books, 2005.

AUTY, Chris, “Poltergeist," Monthly Film Bulletin, n 584, September 1982, 205-6.

CHAUDHURI, Shohini, Feminist Film Theorists, London and New York, Routledge, 2006.

DE FELITTA, Frank, The Entity, New York, Putnam's Sons, 1978.

GILI, Jean, “Poltergeist. La vengeance du téléviseur,” Positif, n² 262, December 1982, 68-9.

GRANT, Barry Keith, ed., The Dread of Difference: Gender and the Horror Film, Austin, University of Texas Press, 1995.

GRIVEL, Daniele and Roland LACOURBE, Robert Wise, Paris, Edilig, 1985.

JACKSON, Shirley, The Haunting of Hill House, New York, Penguin Books, 2006.

KING, Stephen, Danse Macabre, New York, Berkley Books, 1983.

LENNE, Gérard, Histoires du cinéma fantastique, Paris, Seghers, 1989. 
MALTBY, Richard, Hollywood Cinema: An Introduction, Oxford \& Cambridge (MA), Blackwell Publishers, 1995.

MARDORE, Michel, “Les folles du logis. The Haunting," Cahiers du Cinéma, n 155, mai 1964, 50-2.

MERCK, Mandy, ed., The Sexual Subject: A Screen Reader in Sexuality, London \& New York, Routledge, 1999.

NEALE, Steve, Genre and Hollywood, London \& New York, Routledge, 2000.

RODDICK, Nick, “The Entity”, Monthly Film Bulletin, n586, November 1982, 263-4.

SHARRETT, Christopher and Grant, Keith, eds., Mythologies of Violence in Postmodern Media, Detroit, Wayne State University Press, 1999.

SCHNEIDER, Steven Jay, Horror Film and Psychoanalysis. Freud's Worst Nightmare, Cambridge, Cambridge University Press, 2004.

STAIGER, Janet, Media Reception Studies, New York \& London, New York University Press, 2005.

TESSON, Charles, "La neige du téléviseur," Cahiers du Cinéma, n³40, October 1982, 55-9.

UZAL, Marcos, "Nous n'irons jamais nulle part. Les Autres, (Alejandro Amenabar, 2001)," Vertigo, Hors-Série November 2003, “La maison,” Marseille, Images En Manœuvres, 2003.

VERNET, Marc, Figures de l'absence, Paris, Cahiers du Cinéma, 1988.

\section{Filmography}

FURIE, Sidney, The Entity, Twentieth Century Fox, 1981.

HOOPER, Tobe and Steven SPIELBERG, Poltergeist, United International Pictures-MGM Entertainment, 1982.

LENI, Paul, The Cat and the Canary, Universal Pictures, 1927 [silent].

ROSENBERG, Stuart, The Amityville Horror, American International Pictures, 1979.

WISE, Robert, The Haunting, MGM, 1963.

\section{NOTES}

1. Cosimo Urbano, “'What's the Matter with Melanie?': Reflections on the Merits of Psychoanalytic Approaches to Modern Horror Cinema" in Steven Jay Schneider, ed., Horror Film and Psychoanalysis. Freud's Worst Nightmare, 25-6.

\section{ABSTRACTS}

Most haunted house narratives, whether literary or filmic, are based on the same basic principle of intrusion of some outside, usually unidentified force which sows the seeds of chaos and destruction within the boundaries of a home. What is particularly fascinating is precisely the way 
in which the group, and most often the family, reacts to this external force. But the whole point is also to determine the exact nature of the threat and to assess who-or what-the intruder is, so as to circumscribe "it" and return the community to some form of normality. In this respect, even though a direct descendant of a more conventional haunted house film genre, the 1980s family horror imposes a reversal of viewpoints. It actually seems to be reverting to some more classical Hollywood narrative structures after the bloodbaths of the previous decade in horror feasts, such as The Hills Have Eyes (1977) or Dawn of the Dead (1978), which argued then for a new form of society. It also demonstrates how the outside-the-norm entity is finally not considered exogenous any more but rather endogenous and how it appropriates and somehow tries to incorporate some, if not all, members of the household.

In his 1981 film The Entity, Sidney Furie stages Barbara Hershey's body (Carla Moran) as a vehicle for the revelation process and in their 1982 Poltergeist, Tobe Hooper and Steven Spielberg also use young Heather O'Rourke (Carol Anne Freeling) as a medium in very different kinds of houses, no longer darkened and isolated in some desolate part of the American East Coast but now part of the West Coast urban sprawl. Not unlike the next houses on the block, sometimes even belonging to the same housing development, they nevertheless come alive through the impetus given by some obscure catalizer. The same question reemerges: what are the true nature and impact of the haunting in such nondescript places?

\section{AUTHOR}

\section{ANNE-MARIE PAQUET-DEYRIS}

University Paris Ouest 